\title{
VEGETATION ON THE WAWEL HILL, CRACOW (POLAND) IN THE EARLY MIDDLE AGES BASED ON THE FRAGMENTARY POLLEN RECORD. ARCHAEOLOGICAL RESEARCH EXCAVATION IN THE BASEMENT OF BUILDING NO. 9
}

\begin{abstract}
Nalepka D., Kukliński A., Walanus A. and Cywa K. 2021. Vegetation on the Wawel Hill, Cracow (Poland) in the early Middle Ages based on the fragmentary pollen record. Archaeological research excavation in the basement of building No. 9. Sprawozdania Archeologiczne 73/2, 287-311.

Palynological research was carried out on layers archaeologically dated to the early Middle Ages in the basement of the former Austrian hospital at Wawel. The interpretation was based on the sparse number of sporomorphs presented in the samples, not on the percentages.

At the end of the first millennium, on the Wawel Hill and in its vicinity, an open landscape developed with a mosaic of plant communities, including ruderal ones, fields, pastures, and meadows, as well as bushes and forests. Sporomorphs reached the analysed area partially naturally, with pollen rain from plants growing at sites in the Wawel Castle itself and from the immediate or further surroundings of the Wawel Hill. Some sporomorphs reached the examined layers because of human activity: partly accidentally during normal life activities, and partly with material goods brought to Wawel for utility purposes. The interpretation is consistent with the results of palaeobotanical studies from other analysed sites in Wawel (Wasylikowa et al. 2006; Nalepka 2009).
\end{abstract}

Keywords: palynology, anthracology, archaeology, early Middle Ages

Received: 02.06.2020; Revised: 17.06.2020; Accepted: 16.10.2021

1 W. Szafer Institute of Botany, Polish Academy of Sciences, Lubicz 46, 31-512 Kraków, Poland, D.Nalepka@botany.pl; ORCID: oooo-0oo2-5624-3488

2 Wawel Royal Castle. Department of Archaeology and Archaeological Reserve, Wawel 5, 31-001 Kraków,

Poland, andrzej.kuklinski@wawelzamek.pl 


\section{INTRODUCTION}

The Wawel Hill in Cracow (Fig. 1A), together with the buildings on its slopes and on its top, has undergone numerous changes in the past, including random natural events and planned or accidental human activity, involving intervention in the geological structure, living nature, and the material that it creates (construction and reconstruction).

Palaeobotanical research on the Wawel Hill commenced after the end of World War II in the 1950s, and continued in the 1970s, always conducted alongside archaeological research (Wasylikowa 1978a; 1978b), when uncovering successive historical layers that could contain plant debris, established cooperation with palaeobotanists. It should be mentioned that the material collected on the Wawel Hill has not always been completely examined, and only some of it has been included in publications along with other palaeobotanical studies. This happened, for example, with the results of palynological investigations from one of the Wawel sites previously studied (at the turn of the 1960s and 1970s) by Wanda Koperowa that were published only in a paper by K. Wasylikowa (Wasylikowa 1978a). However, the principal reason for the lack of paleoenvironmental research is, of course, the inability to collect materials when this would irreversibly destroy the tissue of artefacts. On the Wawel Hill and at Wawel itself, another reason is the absence of layers and sediments containing microscopic organic plant remains (pollen grains and spores). There are usually few of these on archaeological sites, due to the specific requirements enabling the preservation of such remains. The main factor destroying organic residues is aeration under aerobic conditions (Nalepka 1999; Makohonienko and Nalepka 2007).

In analysing palaeobotanical materials from archaeological sites, their specific nature must be considered: not only their potential, but above all their limitations. These, especially the latter, have been described in detail in textbooks, and are summarised, among other places, in published chapters (Makohonienko and Nalepka 2007; Makohonienko 2014). The conclusion is generally the same: "in spite of the limitations resulting from restricted preservation of sporomorphs in sediments, lower concentration values, selective decay and more complicated depositional processes at terrestrial habitats, pollen evidence from archaeological sites is a useful source of archaeological and environmental interpretation" (Makohonienko and Nalepka 2007, 189).

The results of palaeobotanical research have been published from four sites on the Wawel Hill (Fig. 1B). These are the upper terrace of the restored Renaissance Royal Garden (Nalepka 2009) (Fig. 1B: 1), the Early Medieval culture layer analysed by Koperowa (published in Wasylikowa 1978a) (Fig. 1B: 2), the Medieval culture layers analysed by Wasy- 

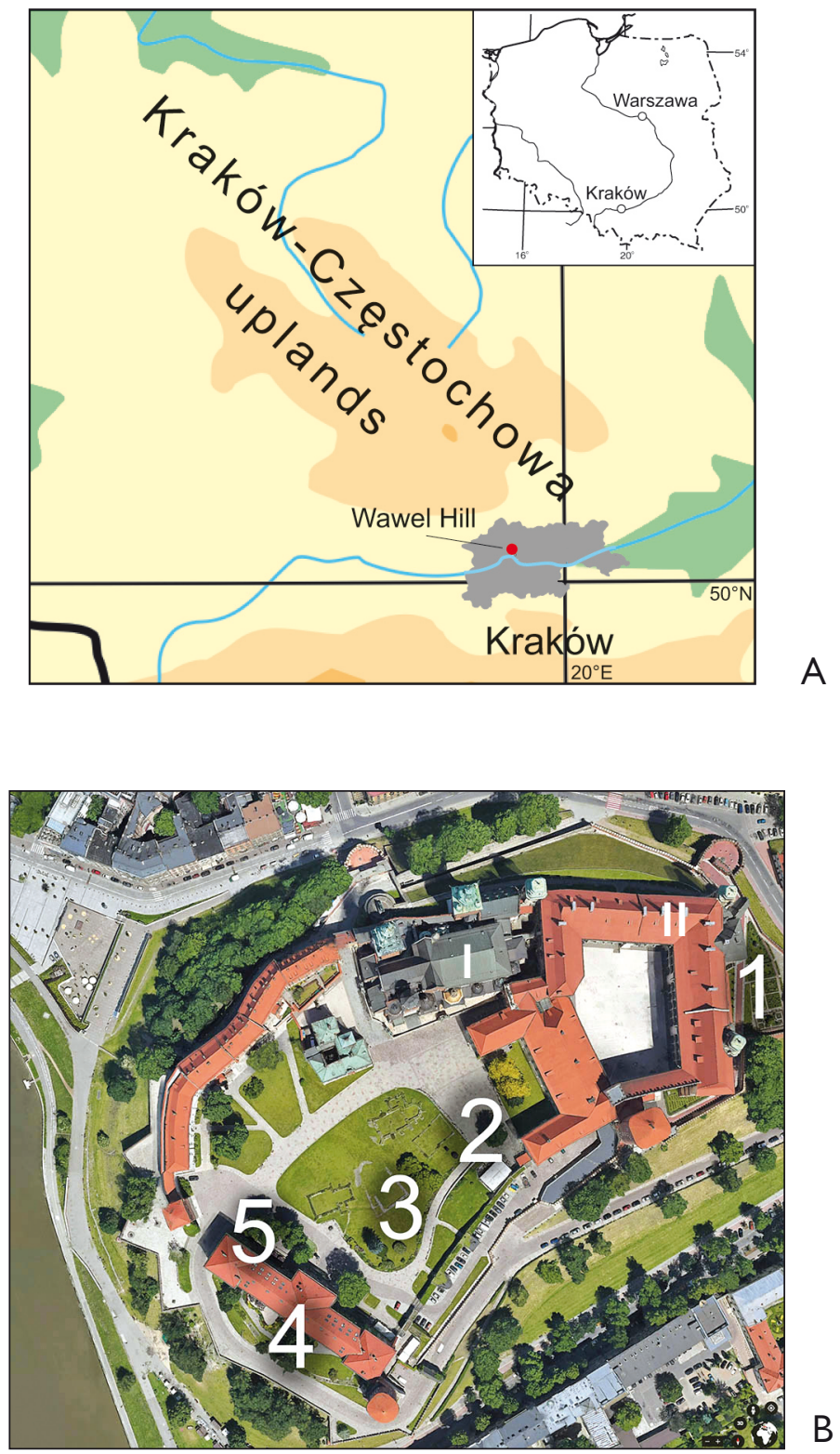

Fig. 1. A - Location of the Wawel Hill; B - Historical and sacral buildings on the Wawel Hill (satellite photo by Google): I - the cathedral, II - the Wawel castle. Sites of palaeobotanical research: 1 - the upper terrace of the restored Renaissance Royal Garden (Nalepka 2009), 2 - the Early Medieval culture layer analysed by Koperowa (published in Wasylikowa 1978), 3 - the Medieval culture layers analysed by Wasylikowa (1991a, b), 4 - the soil sample linked to the early medieval fortifications by Wasylikowa et al. (2006), 5 (sites described in this article) - soil samples in the basement of the building of the former Austrian hospital (after Nalepka 2009, modified) 
likowa (1991) (Fig. 1B: 3), and a soil sample linked to the early medieval fortifications by K. Wasylikowa (Wasylikowa et al. 2006) (Fig. 1B: 4).

The previous studies enabled a partial description of the flora and vegetation of the Wawel Hill and Wawel Castle in the Middle Ages, and provided information about the plants used economically. The history of investigation of the past plant cover of Wawel Hill and the history of human impact at that location were summarised in 2009 by D. Nalepka (Nalepka 2009).

This article presents the results of palynological analysis from a site in the southwestern part of Wawel Hill (Fig. 1B: 5), located in the basement of the building of a former Austrian hospital (building no. 9), from which material was taken for palaeobotanical and radiocarbon dating analyses during the archaeological excavations in 2017. The aim of the study was to describe the vegetation existing during the formation of the studied layers and to indicate their relative age based on palaeobotanical analysis.

\section{ARCHAEOLOGICAL INTRODUCTION}

The subject of the palaeobotanical study is archaeological excavation $1 / 17$ on the Wawel Hill, made in 2017 in region IX in the basement of building no. 9 (Fig. 2: a), a former Austrian hospital from the mid-nineteenth century. It covered a sequence of layers lying at elevations in the range 220.36-218.93 m above sea level (i.e., at a depth of 105 to $143 \mathrm{~cm}$ ), between the concrete floor and the rock surface. The preserved stratigraphic system, including the oldest early medieval layers, is a relic of the settlement, originally developing on the surface of the hill, near its southwestern edge. The complex of layers below the basement floor consists of a layer of weathered degraded clay (rock formations) in places on the surface of the rock, an original soil layer (in places of considerable thickness), early medieval layers, and layers from the early phase of the late Middle Ages (V/VI). Fragments of ancient vessels were extracted from the original soil layer. Most represented the late phase of the Lusatian culture. In the uncovered settlement sequence, the negative foundation of the eastern wall of the Gothic house of confessors was highlighted. It reached the surface of the rock. The foundation pit had been completely excavated (building stone removed), most likely by the builders of the hospital. Probably only the oldest part of the early medieval layers is as follows: 1 ) hearth in a trough pit in the original soil layer (layer VI/9a-b); 2) feature fill (layer VI/8a-b); 3) a layer of hardened charcoal a few centimetres thick (top of layer VI/6); and 4) remains of an unspecified structure (stone cladding and a trench filled with stones that form a foundation), possibly the remains of a residential or production facility (within layer VI/5a-b), preserved in the place of its formation (in situ). The remaining layers (V/VI and VI/1-VI/4), in the form of dumped accumulations, were formed during construction work, including levelling of the area carried out here, and perhaps also during the construction of wood and earth fortifications. 

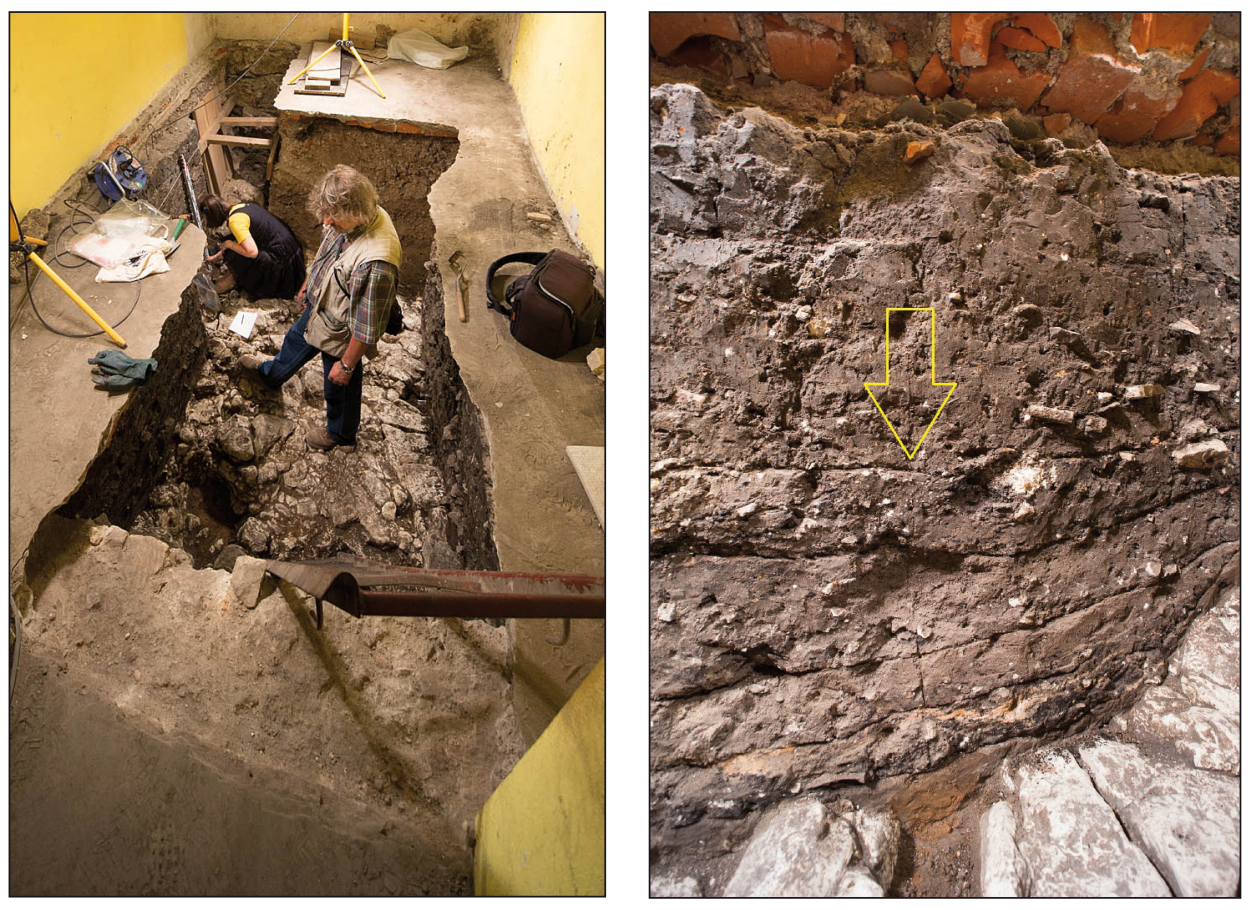

a

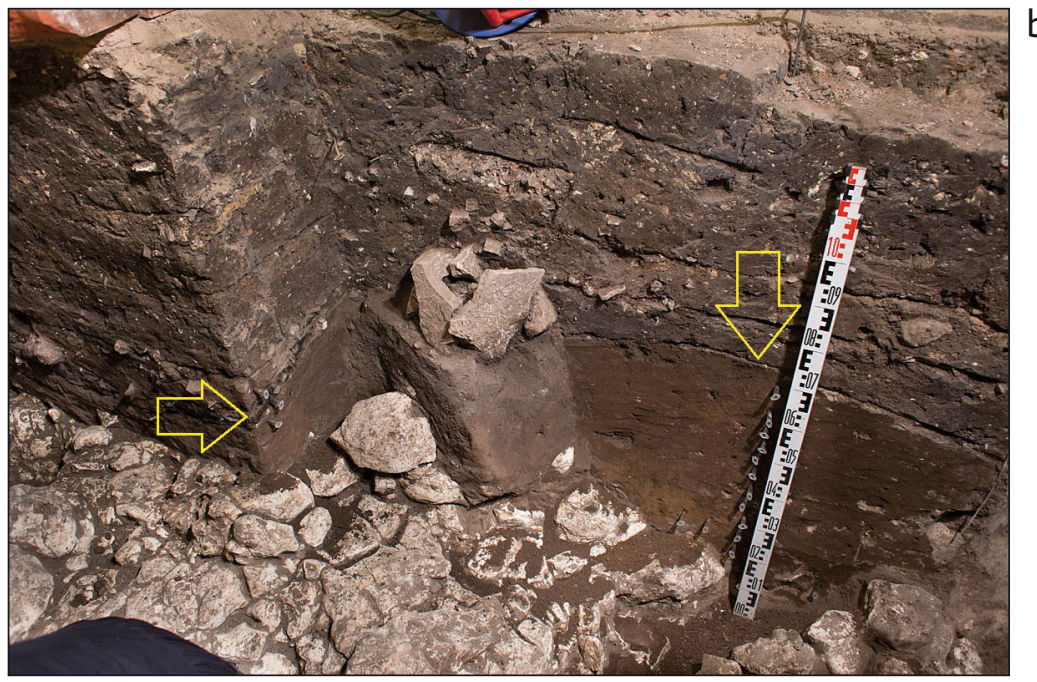

b

Fig. 2. Wawel 2017 site: a - outcrop in the basement of building no. 9; b - the walls in the outcrop; yellow arrows indicate two palaeobotanical sampled profiles: profiles Wawel 2017 NE and Wawel 2017 SE; c - profile Wawel 2017 NW (photo A. Walanus) 
The discovered sequence of layers originates from the period between the $7^{\text {th }}$ or $8^{\text {th }}$ century (?) (oldest) and the second half of the $13^{\text {th }}$ century (youngest). The preserved stratigraphy did not develop undisturbed. The stratification did not systematically increase from level to level, but according to the analysis of archaeological finds (based on analysis of their dating), they underwent transformations, levelling or lowering of the ground level, between the $7^{\text {th }}-8^{\text {th }}$ (?) and $13^{\text {th }}$ century. Therefore, there are no layers, for example, from the $11^{\text {th }}-12^{\text {th }}$ centuries. In the oldest layer (VI/9), a feature (most likely a hearth) is buried in the so-called primary soil. It lies about $21 \mathrm{~m}$ (in a straight line) to the north-east of the palisade relics identified in trench $1 \mathrm{~A} / 91-92$ (region IX), which were originally the inner wall of the rampart, and $14.5 \mathrm{~m}$ from the line of the edge of the clay embankment (slopes - see excavation $1 \mathrm{~B} / 92-94$, region IX) stabilising the palisade from the inside of the castle. The lack of archaeological research between excavations $1 \mathrm{~A}-1 \mathrm{~B}$ and $1 / 17$, as well as the distance separating them, will make it impossible to determine the stratigraphic relationships, and thus the sequences in time, of the oldest layers in excavation $1 / 17$, with relics of early medieval defensive walls discovered in excavations 1A-1B/91-94 (Kukliński 2016). The stratigraphic context of the object (hearth) found in excavation $1 / 17$ in the original soil layer and remains of the primary soil layer in excavation 1B/92-94 - mostly levelled, in connection with the foundation of wood-earth fortifications (see cross-section wall $\mathrm{S}$ of excavations 1A-1C/91-96, region IX; Kukliński 2016, Figs. 2 and 3) - as well as early dating of the site from excavation $1 / 17$ to the $8^{\text {th }}$ century (?), may, however, indicate that the latter is older than the oldest preserved defensive fortifications of the southwestern part of Wawel. Then it would come from before the construction of the stronghold and would be a trace of the original open settlement. At present, this is a hypothesis.

The contemporary location of excavation $1 / 17$, i.e., the deep basement of building no. 9, determines the condition of the cultural layers. Only the portion of the sequence of layers accumulating in prehistory from the rock surface to the surface of the ground in the first half of the $2 \mathrm{O}^{\text {th }}$ century that lies below the basement level, has survived. The remaining layers lying above were partially destroyed during the construction of the foundations of the Austrian hospital, and then during the expansion of the basement rooms in the period between World Wars I and II or during the German occupation (the plans of the hospital building dated around 1860 show that its southwestern range was not originally a basement). Since the construction of the hospital in the years 1854-1855, the preserved layers within the walls have been fully isolated from external influences such as atmospheric precipitation.

\section{MATERIAL}

In the summer of 2017, when the archaeological trench was finally dug, a palynologist was invited to take samples for palaeoecological research. Three exposed walls in the trench, approximately rectangular (c. $300.0 \mathrm{~cm}$ long, c. $150.0 \mathrm{~cm}$ wide and c. $100.0 \mathrm{~cm}$ 
deep) (Fig. 2: a), were sampled. The first profile (Wawel 2017 NE) was located on the north-east wall (fig. 2: b), the second (Wawel 2017 SE) on the south-east wall (Fig. 2: b), and the third (Wawel $2017 \mathrm{NW}$ ) on the north-west wall (Fig. 2: c).

The sampled sediment was heterogeneous, dry, partly consolidated and partly unconsolidated. Samples for palaeobotanical analyses were taken from each distinct lithological layer, starting from the middle and bottom layers, which seemed unmixed (Fig. 2: b). Samples for pollen analysis were collected from the deepest to the uppermost layers, directly into plastic tubes (ca. 1-4 $\mathrm{cm}^{3}$ ), and additional material (a few $\mathrm{cm}^{3}$ of sediment) was collected in plastic bags. The samples taken were numbered in order from the bottom to the top layer. Next, several additional samples were collected for macrofossil analysis. The thickness of each sample was not greater than 2.0-3.0 $\mathrm{cm}^{3}$, and the volume was c. $0.50 \mathrm{dm}^{3}$. Samples were taken by Professor Dorota Nalepka (palynologist, palaeobotanist) in the presence of archaeologist Dr Andrzej Kukliński.

During the analysis of archaeological sources, two radiocarbon dates of charcoal samples taken from the hearth layer (VI/9) and a hardened layer of charred wood debris, possibly part of a destroyed indeterminate wooden structure, which seem to be wattlework (Fig. 3) (Layer VI/6 upper part) were obtained by the archaeologist Dr A. Kukliński, who had them dated by the Radiocarbon Laboratory in Poznań.

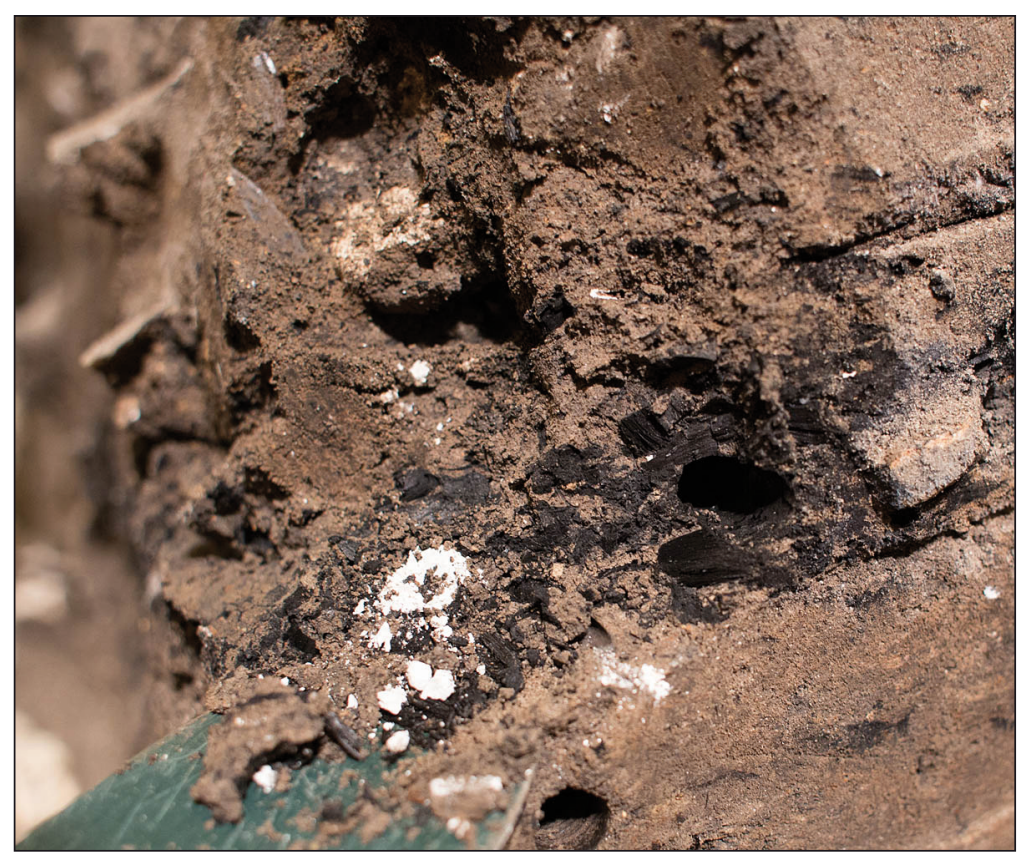

Fig. 3. View of the wall of the Wawel 2017 NE profile after sampling for palynological analysis (13-15) with probable fragments of wattlework (photo: A. Walanus) 
Drawings were made by Dr A. Kukliński, and photographic documentation by Professor Adam Walanus. From the beginning, the material was kept in the cold store of the Institute of Botany, Polish Academy of Sciences. Part of the collected material was used for palynological and plant macroremains analyses. All of the remaining material was forwarded for further analysis to the geologist.

\section{LABORATORY METHODS}

All samples for pollen analysis were prepared using standard procedures. Each sample of $1 \mathrm{~cm}^{3}$ was treated with Erdmann acetolysis (Faegri et al. 1989), together with the addition of a known number of indicator spores of Lycopodium (Stockmarr 1971). Mineral components were removed by boiling in $10 \% \mathrm{KOH}$, decantation, and boiling in hydrofluoric acid (HF). The hydrofluoric acid procedure was repeated for some of the samples where clay remained, preventing microscopic preparation. Additional mineral elements were removed by treatment with hot tetrasodium pyrophosphate $\mathrm{Na}_{4} \mathrm{P}_{2} \mathrm{O}_{7}$ (sodium diphosphate) and ultrasound disaggregation. Finally, to remove the finest fraction, the material was screened through a sieve with a mesh diameter less than 10 micrometres. The material was then mounted in glycerine (Berglund and Ralska-Jasiewiczowa 1986).

Pollen analysis was performed using a Nikon microscope with phase contrast and magnification from 600 up to 1000 . Sporomorphs were counted on at least two slides for each sample. The analysed samples contained very low numbers or badly preserved sporomorphs, and some samples did not include any sporomorphs at all. Along with sporomorphs, silt particles, charred particles, and very small, amorphous dark brown particles (probably organic) were present. During the determination of sporomorphs, atlases (e.g. Moore et al. 1991; Beug 2004) and the Reference Collection of National Biodiversity Collection - Herbarium KRAM, KRAM P, Palaeobotanical collection, W. Szafer Institute of Botany, Polish Academy of Sciences in Cracow, were used.

Samples for analysis of plant macroscopic remains (carpological and anthracological analysis) were taken from the same levels as the seven samples for palynological analysis: NW:21, NW:19, NW:17; SE:1, SE:9, SE:12, and NE:13. Samples with a volume of approx. 2-3 $\mathrm{cm}^{3}$ were flooded with distilled water, and after two days they were sieved through a $0.2 \mathrm{~mm}$ sieve. The sediment was almost completely decomposed in the water. The residue was removed after the macroscopic remains analysis and anthracological analysis.

In the field of view of the microscope slides, very numerous, dark brown, small (up to 10 microns) fragments of plant tissues were present, mostly amorphous. In one sample from the Wawel 2017 NE: 13 profile, such fragments were slightly larger than the others (up to 30 microns). These could have been charred pieces of wood, but they were still too small to be suitable for botanical determination. Sporomorphs were not present in most of the analysed samples, except for three samples in the upper parts of each profile analysed. 
Table 1. Radiocarbon dating (AMS) (Goslar, Report 2019) Given are intervals of calendar age, where the true ages of the samples encompass with the probability of c. $68 \%$ and c. $95 \%$. The calibration was made with the OxCal software. OxCal v4.2.3 Bronk Ramsey (2013); r:5; IntCal13 atmospheric curve

(Reimer et al. 2013)

\begin{tabular}{|l|l|c|c|c|c|}
\hline \multicolumn{1}{|c|}{ Layer } & \multicolumn{1}{|c|}{ Dated material } & No of sample & ${ }^{14} \mathbf{C ~ B P}$ & $\begin{array}{c}\text { Age AD } \\
\mathbf{6 8 . 2 \%} \\
\text { probability) }\end{array}$ & $\begin{array}{c}\text { Age AD } \\
\mathbf{9 5 . 4 \%} \\
\text { probability) }\end{array}$ \\
\hline $\begin{array}{l}\text { Top part of the } \\
\text { furnace layer } \\
\text { (VI/9) }\end{array}$ & $\begin{array}{l}\text { Charcoal samples taken from } \\
\text { the hearth layer }\end{array}$ & 2_PB z 68 & $1140 \pm 30$ & $880-970$ & $\begin{array}{r}777-793 \\
802-848 \\
855-981\end{array}$ \\
\hline VI/6 upper part & & & & $629-748$ \\
& $\begin{array}{l}\text { Hardened layer of charred } \\
\text { wood debris, possibly } \\
\text { destructible indeterminate } \\
\text { wooden structure } \\
\text { (wattlework?) }\end{array}$ & 1_PB_10 z 45 & $1220 \pm 30$ & $726-738$ & $768-779$ \\
& & & $789-870$ & \\
\hline
\end{tabular}

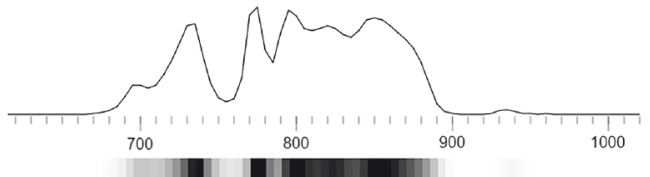

Radiocarbon determination: $1220 \pm 30.95 \%$ confidence: $705-880 \mathrm{BC}$, median: $805 \mathrm{BC}$

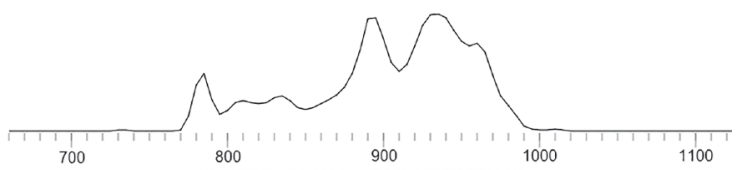

Radiocarbon determination: $1140 \pm 30.95 \%$ confidence: 780 - 975 BC, median: 910 BC

Fig. 4. Visualisation of ${ }^{14} \mathrm{C}$ date calibration results from the Wawel 2017 site (Table 1) (https://adamwalanus.pl/c14cal.html)

The residuum (residue after sludging) consisted of grains of sand and a few small lumps of agglutinated mineral material that crumbled when touched with a preparation needle. Almost no plant remains found in the lumps could be identified. Only one sample, Wawel 2017 NW:19, contained a few charred wood fragments, with dimensions of 0.3-0.5 mm, which were determined (Dr Katarzyna Cywa) and a few smaller, charred plant fragments, not identified due to their small size. Similarly, in samples from the Wawel 2017 NW profile, there were found single, small pieces of burned plant debris, but these were unsuitable for identification due to their small size. Above that, the residuum contained very small, dark brown, indeterminate plant tissue fragments. The material did not contain identifiable plant macroscopic remains in the form of fruit, seeds, or plant tissue residues.

Pollen diagrams and pie plots were created using the POLPAL program (Nalepka and Walanus 2003: https://adamwalanus.pl/Polpal.html). 
The hardened layer of charred wood debris, a possibly destroyed wooden structure, which seems to be wattlework (top of Layer VI/6), is dated with a probability of $68.2 \%$ to the intervals 726-738 $\mathrm{AD}$ (7.3\%), 768-779 $\mathrm{AD}$ (7.9\%) and 789-870AD (53\%), and at a confidence level of $95.4 \%$ to the ranges $629-748 \mathrm{AD}$ (20.9\%) and $762-887 \mathrm{AD}$ (74.5\%).

The date of the sample taken from the charcoal hearth layer and the upper part of the furnace layer (VI/9) is between 880 and $970 \mathrm{AD}$ (with a probability of $68.2 \%$ ), and with 95.4\% probability lies in the ranges 777-793 $\mathrm{AD}$ (5.5\%), 802-848 $\mathrm{AD}(11.3 \%)$ and 855$981 \mathrm{AD}$ (78.6\%) (Goslar 2019) (Table 1, Fig. 4).

\section{PROFILE WAWEL 2017 SE}

Samples from the Wawel 2017 SE profile were taken from a dark brown, cohesive mineral layer. The layer overlay the calcareous rock, and covered with dry, heterogeneous mineral layers - according to the archaeologist's assessments these were cultural layers (Fig. 5, Table 2).

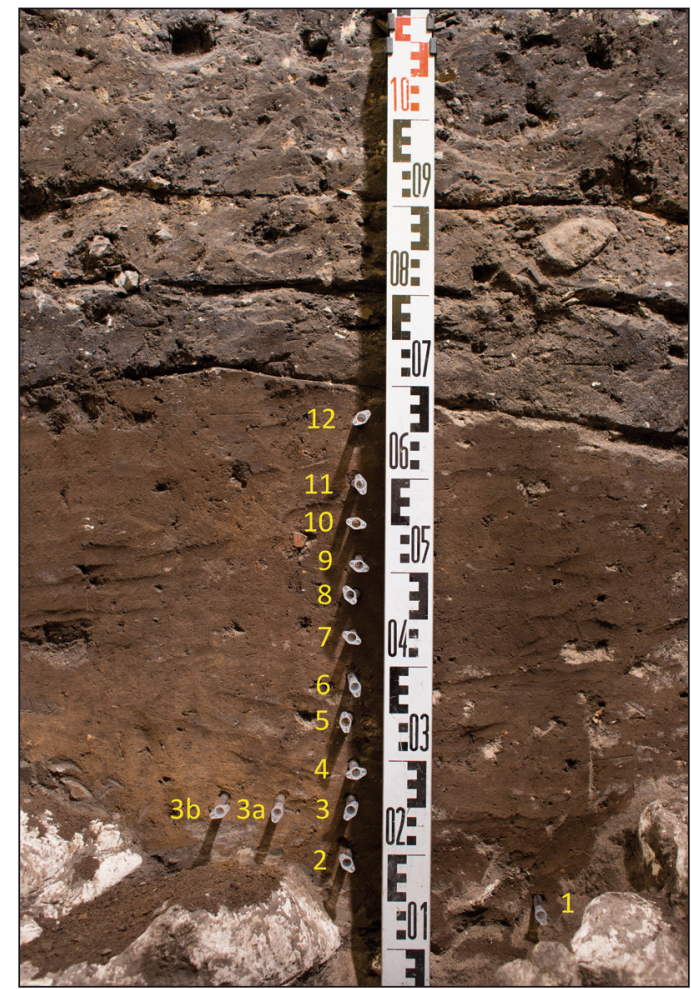

Fig. 5. Wall of the Wawel 2017 SE profile with marked sampling locations for palynological analysis (1-12) (photo: A. Walanus) 
Table 2. Description of the excavated profile Wawel 2017 SE

\begin{tabular}{|l|l|l|}
\hline \multicolumn{1}{|c|}{$\begin{array}{c}\text { Designation of } \\
\text { layer }\end{array}$} & No of samples & \multicolumn{1}{c|}{ Sediment description } \\
\hline & & $\begin{array}{l}\text { Mineral, compact brown layer, covered with a heterogeneous } \\
\text { mineral }\end{array}$ \\
\hline the original soil \\
layer & $4-12$ & $\begin{array}{l}\text { Black, non-coherent with scattered fragments of charred plant } \\
\text { fragments (?) the cultural layer }\end{array}$ \\
\cline { 2 - 4 } & $1,2,3,3 \mathrm{a}, 3 \mathrm{~b}$ & Homogeneous, compact mineral dark brown, with humus \\
\hline
\end{tabular}

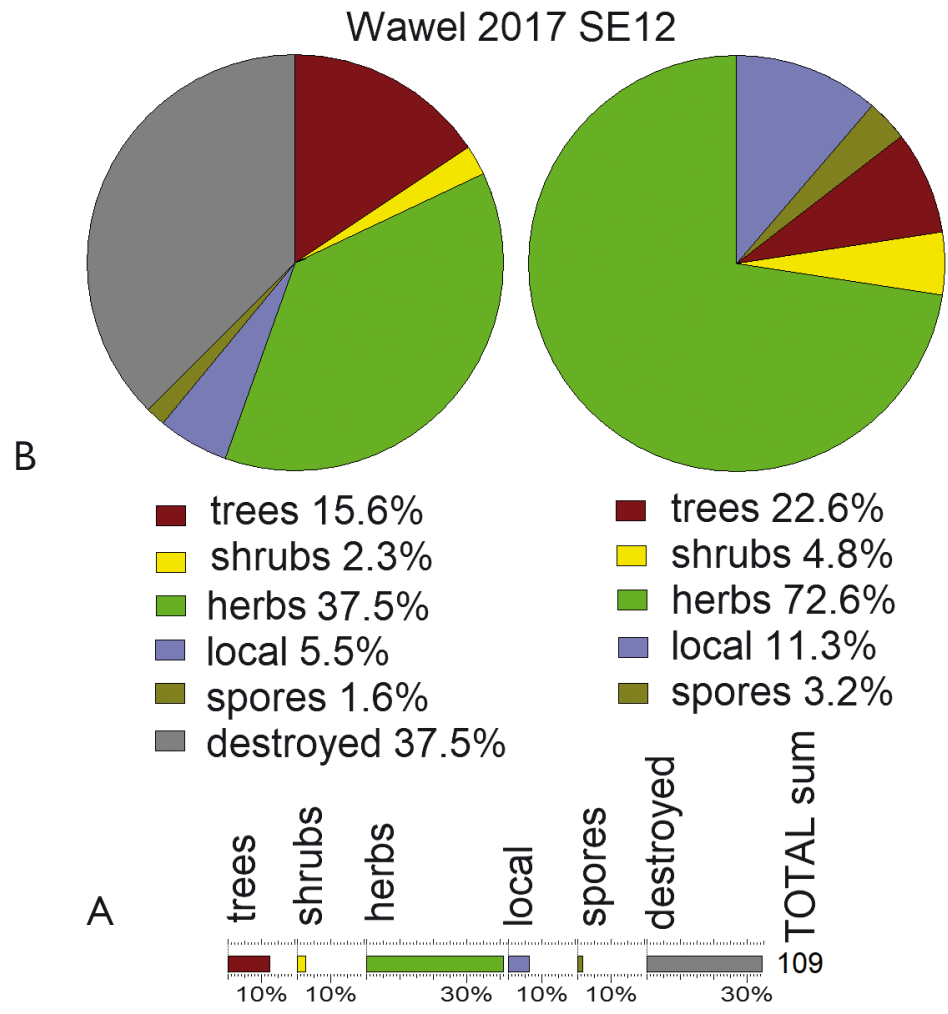

Fig. 6. Results of palynological analysis of sample no. 12 in the Wawel 2017 SE profile. Percentages of sporomorphs in the studied spectrum presented in groups: trees, shrubs, herbaceous plants, local habitat plants, spores of non-vascular plants and unidentified sporomorphs. A - percentage diagram, B - percentage piechart, $\mathrm{C}$ - percentage pie graph in relation to the sum of identified sporomorphs (excluding sporomorphs destroyed and impossible to determine)

In the palynological samples SE:1, SE:3, SE:9, few sporomorphs were present (Fig. 6); they represented taxa of herbaceous trees and plants, as well as sporomorphs not identified due to a significant degree of destruction (Corroded). 


\section{PROFILE WAWEL 2017 NE}

Samples from the Wawel 2017 NE profile were taken from three distinctly different layers. The bottom brown mineral sediment was cohesive. The middle, black, cohesionless sediment (according to expert archaeological assessment: a cultural layer) contained burned plant fragments. Above this was cohesive, brown mineral sediment. The whole profile was covered by heterogeneous mineral sediment (Fig. 7, Table 3).

Table 3. Description of the excavated profile Wawel 2017 NE

\begin{tabular}{|l|c|l|}
\hline \multicolumn{1}{|c|}{ Designation of layer } & No of samples & \multicolumn{1}{c|}{ Sediment description } \\
\hline VI/8b & 15 & Brown, mineral coherent \\
\hline VI/9a & 14 & Cohesionless, black, with charred plant fragments (?) \\
\hline Original soil layer & 13 & Brown, mineral coherent \\
\hline
\end{tabular}

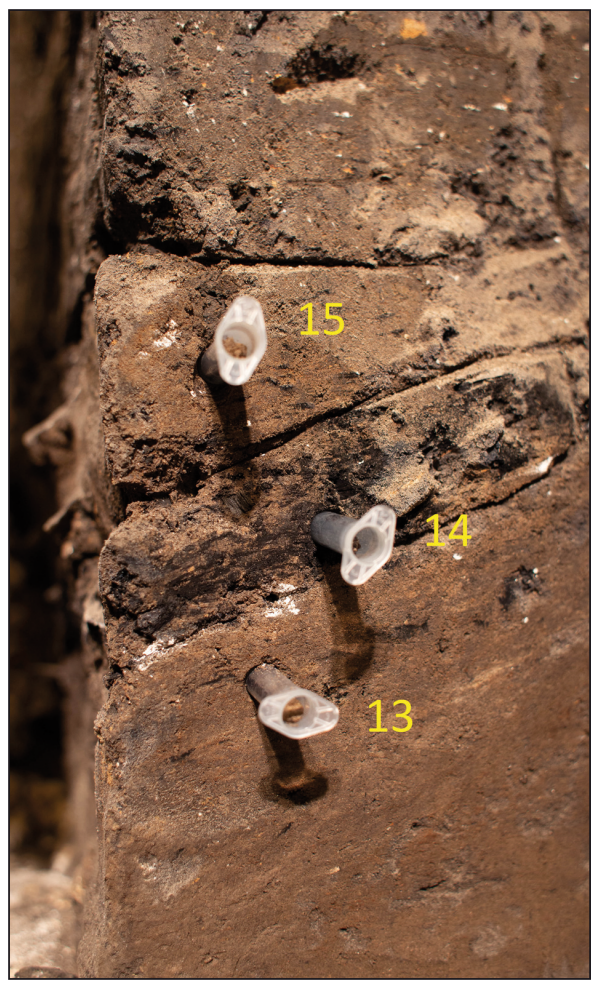

Fig. 7. Wall of the Wawel 2017 NE profile with marked sampling locations for palynological analysis (13-15) (photo: A. Walanus) 
In two palynological samples (NE:14 and NE:15) from the Wawel 2017 NE profile, only single pollen grains of Pinus, Tilia, Cerealia undiff., Poaceae, Cichorioideae and Asteraceae were present, as well as sporomorphs not identified due to the significant degree of destruction (labelled as corroded and degraded). In sample NE:13 sporomorphs were not found.

According to the archaeologist, Dr A. Kukliński, the heterogeneous, black layer with white lumps from which sample no. 14 (profile Wawel 2017 NE) was taken, with larger fragments of plants and pottery fragments visible, is probably the remains of a medieval hearth (furnace). Analysing plant residues in the material, no larger plant fragments, including burned wood, were found that could be used for determination.

\section{PROFILE WAWEL 2017 NW}

Samples from the Wawel 2017 NW profile were taken from several different layers: from a dark brown, cohesive, compact sediment overlying the calcareous rock, and from another, distinctively mineralised, less cohesive, possibly charred (cultural) sediment. The highest sediment, from which sample no. 21 was taken, was covered with dry, heterogeneous mineral substance (Fig. 8, Table 4).

According to the archaeologist, Wawel 2017 NE and Wawel 2017 NW are the same profile, separated by a research excavation trench. Sample no. 15 (from NE) corresponds to sample no. 21 (from NW). Sample no. 14 (NE) corresponds to sample no. 19 (and maybe 20) from NW.

In the NW:21 palynological sample, 270 sporomorphs were counted (Fig. 9), representing taxa of trees and herbaceous plants, as well as sporomorphs not identified due to a significant degree of destruction (corroded, degraded). In the NW:16 and NW:19 palynological samples from the Wawel 2017 NE profile, only single sporomorphs were present. In the NW:18 sample, no sporomorphs were found.

Table 4. Description of the excavated profile Wawel 2017 NW

\begin{tabular}{|l|c|l|l|}
\hline Designation of layer & $\begin{array}{c}\text { No of } \\
\text { samples }\end{array}$ & $\begin{array}{c}\text { Corresponds to } \\
\text { the sample no }\end{array}$ & \multicolumn{1}{|c|}{ Sediment description } \\
\hline VI/8a-b & 21 & $15(\mathrm{NE})$ & Mineral, homogenous, brown \\
\hline \multirow{2}{*}{ VI/9a-b } & 20 & $14(\mathrm{NE})$ probably & $\begin{array}{l}\text { Mineral (sand), heterogeneous red, with white } \\
\text { mineral inclusions }\end{array}$ \\
\cline { 2 - 4 } & 19 & $14(\mathrm{NE})$ & $\begin{array}{l}\text { Mineral, heterogeneous, black, with charred plant } \\
\text { fragments (?) }\end{array}$ \\
\hline $\begin{array}{l}\text { Degraded clay (rock } \\
\text { formations) }\end{array}$ & 17,18 & & Mineral, homogenous, light brown \\
\cline { 2 - 4 } & 16 & & Mineral, cohesive, compact, dark brown \\
\hline & & & Limestone rock \\
\hline
\end{tabular}




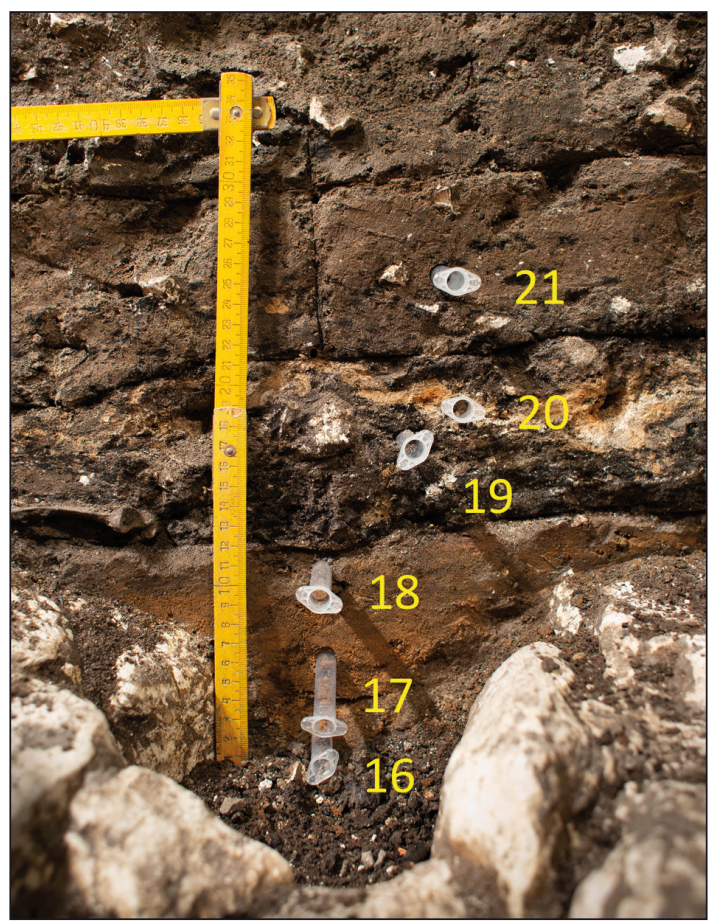

Fig. 8. Wall of the Wawel $2017 \mathrm{NW}$ profile with marked sampling locations for palynological analysis (16-21) (photo: A. Walanus)

In the Wawel $2017 \mathrm{NW}$ profile, from which sample no. 19 was taken, the small, charred wood fragments were identified as oak (Quercus) and hornbeam (Carpinus). In the palynological sample, hornbeam pollen grains were not identified.

\section{DISCUSSION}

\section{Site Wawel 2017}

At the Wawel 2017 site, in the two analysed SE and NW profiles, sporomorphs were present only in the upper layers of the excavated profiles from which samples were taken for analysis. These layers are covered with overlaying layers, from which samples were not collected, as it was considered that the material was mixed and may not contain sporomorphs (Figs. 5, 7, 8).

In the composition of the sporomorphs of both profiles, over $30 \%$ are damaged sporomorphs, unsuitable for taxonomic determination. Among the identified sporomorphs, 
herbaceous taxa predominate (over 70\%). These are represented by pollen grains from the family Cichorioideae, which due to their highly resistant cell walls (exine) are usually overrepresented in samples from archaeological sites (Makohonienko and Nalepka 2007). Pollen from plants in the families Rosaceae, Asteraceae and Poaceae (grasses) are also present. There are also individual pollen grains of cereals with genus not identified (Cerealia undiff.). The percentages of trees (about 20\%) and shrubs (about 5\%) (Figs. 6, 9) in both profiles are similar.

The taxonomic composition of the Wawel 2017 NW profile, in which 270 plant taxa were identified, and the Wawel 2017 SE profile, in which 62 taxa were identified, allows a very general description of the vegetation growing near the examined site. Based on the composition of sporomorphs (Table 5), it can be concluded that they originated from a variety of plant communities, among which communities developing in an open (nonforested) landscape dominated. Fresh and moist meadows with Cirsium, Carduus, Fili-
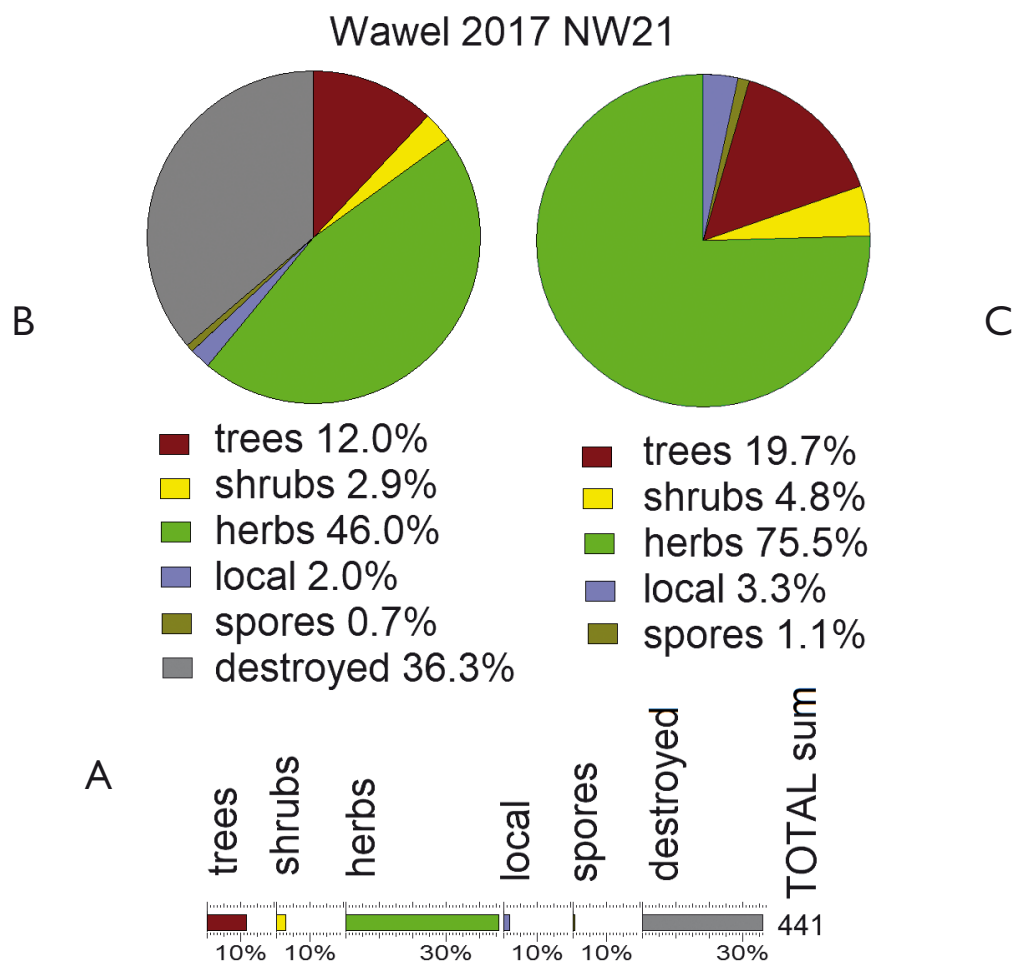

Fig. 9. Results of palynological analysis of sample no. 21 from the Wawel 2017 NW profile. Percentage of sporomorphs in the studied spectrum presented in groups: trees, shrubs, herbaceous plants, local habitat plants, spores of non-vascular plants and unidentified sporomorphs A - percentage diagram, B - percentage piechart, $\mathrm{C}$ - percentage pie graph in relation to the sum of identified sporomorphs (excluding sporomorphs destroyed and impossible to determine) 
Table 5. List of sporomorphs (pollen grains and spores) identified in the analysed Wawel 2017 NW, Wawel 2017 SE and Wawel 2017 NE profiles.

Palynological taxa arranged in groups depending on the possibility of indicating habitat requirements

\begin{tabular}{|c|c|c|c|}
\hline \multirow{2}{*}{ Sporomorphs (identified palynological taxa)* } & \multicolumn{3}{|c|}{ Profile Wawel 2017} \\
\hline & NW & SE & NE \\
\hline \multicolumn{4}{|l|}{$\begin{array}{l}\text { Taxa determined to the species. } \\
\text { Habitat requirements specified exactly }\end{array}$} \\
\hline Fagus sylvatica & & 1 & \\
\hline Fraxinus excelsior & 1 & & \\
\hline Pinus sylvestris & 1 & 1 & 1 \\
\hline Corylus avellana & 1 & 1 & \\
\hline Juniperus communis & 1 & & \\
\hline Polygonum bistorta & 1 & & \\
\hline Sanguisorba officinalis & 1 & & \\
\hline Secale cereale & 1 & & \\
\hline Solanum dulcamara & 1 & 1 & \\
\hline Typha latifolia & 1 & 1 & \\
\hline Pteridium aquilinum & & 1 & \\
\hline \multicolumn{4}{|l|}{$\begin{array}{l}\text { Taxa determined to the genera. } \\
\text { Habitat requirements specified in some approximation, imprecise }\end{array}$} \\
\hline Acer & 1 & & \\
\hline Alnus & 1 & 1 & \\
\hline Betula & 1 & 1 & \\
\hline Populus & & 1 & \\
\hline Quercus & 1 & 1 & \\
\hline Tilia & 1 & & 1 \\
\hline Salix & 1 & & \\
\hline Artemisia & 1 & & \\
\hline Campanula & 1 & & \\
\hline Filipendula & 1 & & \\
\hline Lythrum & 1 & & \\
\hline Thalictrum & 1 & 1 & \\
\hline Cirsium/Carduus & 1 & & \\
\hline
\end{tabular}




\begin{tabular}{|c|c|c|c|}
\hline \multirow{2}{*}{ Sporomorphs (identified palynological taxa)* } & \multicolumn{3}{|c|}{ Profile Wawel 2017} \\
\hline & NW & SE & NE \\
\hline \multicolumn{4}{|l|}{$\begin{array}{l}\text { Taxa determined to the genera. } \\
\text { Habitat requirements specified in some approximation, imprecise }\end{array}$} \\
\hline Rumex acetosa/acetosella & 1 & & \\
\hline \multicolumn{4}{|l|}{$\begin{array}{l}\text { Taxa determined to the family. } \\
\text { Habitat requirements specified in a small approximation, imprecise }\end{array}$} \\
\hline Ericaceae & & 1 & \\
\hline Apiaceae & 1 & 1 & \\
\hline Asteraceae & & & 1 \\
\hline Brassicaceae & 1 & & \\
\hline Caryophyllaceae & 1 & & \\
\hline Chenopodiaceae & 1 & & \\
\hline Cichorioideae & 1 & 1 & 1 \\
\hline Cyperaceae & 1 & 1 & \\
\hline Poaceae & 1 & 1 & 1 \\
\hline Rosaceae & 1 & 1 & \\
\hline Equisetum & 1 & 1 & \\
\hline \multicolumn{4}{|l|}{$\begin{array}{l}\text { Taxa determined to the group. } \\
\text { Habitat requirements specified in a small approximation, imprecise }\end{array}$} \\
\hline Cerealia undiff. & 1 & 1 & 1 \\
\hline \multicolumn{4}{|l|}{$\begin{array}{l}\text { Taxa determined to the palynological type. } \\
\text { Habitat requirements defined very general and ambiguous. } \\
\text { The range of habitats can vary widely. } \\
\text { Some taxa are cosmopolitan habitat }\end{array}$} \\
\hline Aster-type & 1 & 1 & \\
\hline Centaurea scabiosa-type & 1 & & \\
\hline Centaurea jacea-type & 1 & & \\
\hline Centaurea mollis-type & 1 & & \\
\hline Campanula-type & 1 & & \\
\hline Lychnis-type & 1 & & \\
\hline Prunella-type & 1 & & \\
\hline Dianthus-type & 1 & & \\
\hline Caltha-type & 1 & & \\
\hline Trifolium-type & 1 & & \\
\hline
\end{tabular}




\begin{tabular}{|c|c|c|c|}
\hline \multirow{2}{*}{ Sporomorphs (identified palynological taxa)* } & \multicolumn{3}{|c|}{ Profile Wawel 2017} \\
\hline & NW & SE & NE \\
\hline Mentha-type & 1 & 1 & \\
\hline Carduus -type & & 1 & \\
\hline Cirsium-type & 1 & & \\
\hline Galium-type & 1 & & \\
\hline Anthemis-type & 1 & 1 & \\
\hline Rumex acetosella-type & 1 & & \\
\hline Rumex acetosa-type & 1 & & \\
\hline Vicia-type & 1 & & \\
\hline Sparganium-type & 1 & 1 & \\
\hline \multicolumn{4}{|l|}{$\begin{array}{l}\text { Taxa determined to unclassified group. } \\
\text { Habitat requirements specified in some approximation }\end{array}$} \\
\hline Filicales monolete & & 1 & \\
\hline \multicolumn{4}{|l|}{$\begin{array}{l}\text { Taxa classified into a systematic group. } \\
\text { Habitat requirements specified in some approximation }\end{array}$} \\
\hline Sphagnum & 1 & & \\
\hline Bryales=Musci & 1 & & \\
\hline Botryoccocus & 1 & & \\
\hline \multicolumn{4}{|l|}{ Undetermined taxa. } \\
\hline Indeterminable: concealed = Concealed & 1 & 1 & \\
\hline Indeterminable: corroded $=$ Corroded & 1 & 1 & 1 \\
\hline Indeterminable: degraded = Degraded & 1 & 1 & 1 \\
\hline Indeterminable: unknown = Varia & 1 & 1 & \\
\hline \multicolumn{4}{|l|}{ Other plant microscopic remains } \\
\hline Charcoal & & & 1 \\
\hline
\end{tabular}

* Palynological taxa: sporomorphs (pollen or spores) with the same set of morphological features, grouping plants of different species, genera or families. Taxa of genus or family rank may include species with different ecological requirements, representing different habitats.

pendula, Campanula, Sanguisorba and dry meadows with Centaurea and Dianthus developed here. Growing in wet places and on moist banks of watercourses (rivers/ streams) and water reservoirs (old riverbeds, ponds) were alders (Alnus) and willows (Salix). The presence of cereal pollen (Cerealia undiff.) including wheat (Triticum) may indicate the existence of arable fields near the Wawel Hill (it cannot be determined 
whether they were closer or more distant). Cereals were probably not grown on the Hill; their pollen grains could have been brought to Wawel with deliveries of cereals or flour to the court kitchens.

This is a general (not detailed) picture, but it corresponds to the picture outlined based on palynological analysis from neighbouring palaeobotanical sites analysed on the Wawel Hill (Wasylikowa 1978a; 1978b; 1991; Wasylikowa et al. 2006, Nalepka 2009).

Pollen from ruderal plants (Artemisia) may have come from the immediate surroundings because these plants disperse very quickly (for example, on paths, next to walls) and are not always removed (mowed, plucked) before they bloom and release the mature pollen grains.

The fairly numerous identified sporomorphs indicate the existence of diverse communities growing in habitats with different ecological requirements, since plant pollen from the identified genera classified as (e.g., Aster type) or families (Ericaceae, Brassicaceae, Poaceae, Apiaceae) may have come from plants growing in cosmopolitan habitats.

Sporomorphs reached the studied sediment from nearby habitats, located in the closer or more distant surroundings. Due to the location of the site, the preserved sporomorphs may have arrived there by natural deposition in the form of pollen rain from the area around Wawel Hill, including plants grown near the Hill, or may have come from plants growing directly on it. They could also have been brought to Wawel by human agency with the transport of material goods - for example, among plants delivered to the court kitchens as food for people (Wasylikowa 1991) or as food and for agricultural purposes related to the animals present here.

The presented interpretation describing the vegetation during the formation of the studied sediments at the Wawel 2017 site is consistent with the interpretation of the results of previous palaeobotanical studies obtained from the study of other geological sediment profiles from early medieval layers in region IX at Wawel (Wasylikowa et al. 2006) and from the Royal Gardens on the upper terrace (Nalepka 2009).

\section{Genesis of the filling and the presence of sporomorphs in the examined site}

Analysing the results, the question arises of why pollen is preserved only in the upper layers of each profile studied and has disappeared from the deeper levels.

The heterogeneous nature of the sediment proves the anthropogenic origin of the basin here and its subsequent filling. On the naturally exposed limestone rocks from which the Wawel Hill is built, it was excavated by early medieval people (from the early tribal period?). Later, the contents of this depression were levelled several times, and then the feature was filled again with various materials, such as furnace remains. The sediment filling the depression was uneven (loose), so sporomorphs that may have fallen naturally along with pollen rain would have quickly decomposed under aerobic condi- 
tions. After some time, the natural process of growth of vegetation could begin on the surface of the filling. This resulted in a moist organic layer in which sporomorphs could have been preserved, but this layer was backfilled after a short time. This is in accordance with the archaeological description quoted above: The sequence of the feature's fill is covered by a partially humidified sandy layer that covers its entire area (layer VI/8). This layer may be a testimony to the plan of levelling and tidying of the place of operation of the furnace after its use.

\section{The age of the analysed sediment estimated based on relative and absolute dating \\ Palynological (relative) age}

The material taken from profiles at the Wawel 2017 site can be dated to the late Holocene, based on the composition of sporomorphs. This is evidenced by the presence of beech pollen (Fagus sylvatica), a so-called "late migrant" (Latałowa et al. 2004). Based on the presence of rye pollen (Secale cereale), one can point to the Subatlantic phase (Okuniewska-Nowaczyk et al. 2004). Based on the pollen analysis, there is no possibility of specifying the age more precisely.

\section{Archaeological (relative) age}

The archaeologist, Dr Andrzej Kukliński, based on evaluation of the archaeological artefacts and their position, dated the exposed sequence of cultural layers to no older than the $8^{\text {th }}$ century $\mathrm{AD}$.

\section{Radiocarbon (absolute) age}

Radiocarbon dates obtained by the AMS method did not confirm the dating - they indicated that the material is slightly younger, from the $8^{\text {th }}$ and $9^{\text {th }}$ centuries, and in reverse sequence (Kukliński in print). Palynological/palaeobotanical studies did not provide grounds for a precise specification of the age of the examined sediments.

\section{Comparison of palynological data from three sites examined on the Wawel Hill}

Another interpretation was based on the analysis of materials taken from three places: (Fig 1B: 4) from the site marked as Wawel IX, from a clump of organic material stuck together with mineral matter (Wasylikowa et al. 2006), (Fig. 1B: 1) from the sediments deposited in the Renaissance Royal Gardens at Wawel, which are known to have been 


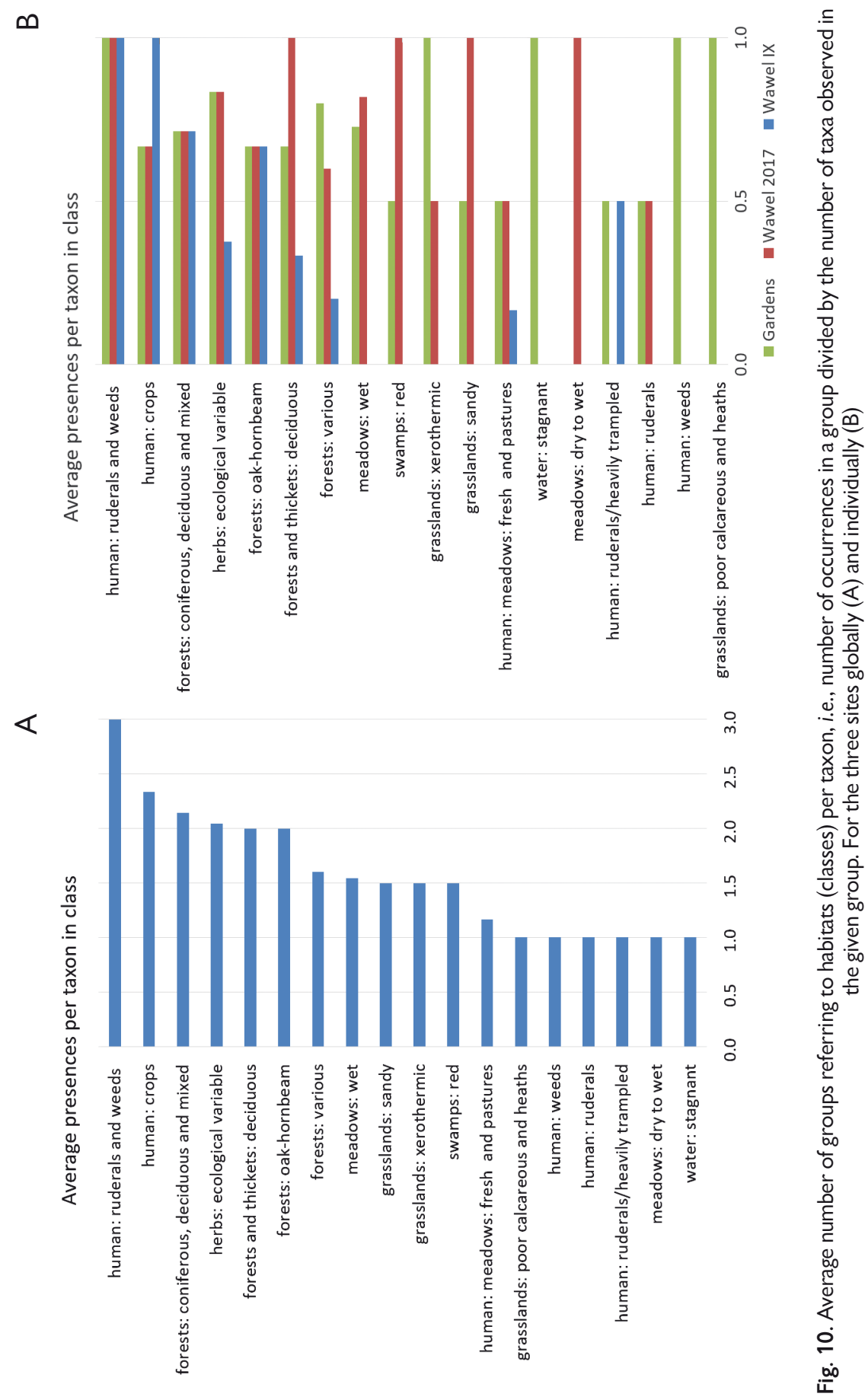


transported there in bulk (Gwizdałówna 1995, after Chmiel 1933; Nalepka 2009), and (Fig. 1B: 5) from three profiles located in the basement of building no. 9 (described in this article). The pollen diagram made by Koperowa (Wasylikowa 1978a) is excluded from the discussion, because although the set of palynological taxa of herbaceous plants which she distinguished is very numerous, not all of the determinations have been confirmed using modern literature data.

At the beginning of the work on the pollen data, the interpretation and discussion were based on percentage pollen diagrams/pie charts (Figs. 6, 9) in a standard way (Makohonienko and Nalepka 2007). However, due to the small number of sporomorphs in the samples, raw diagrams/pie charts were prepared based on raw data ( $c f$. Nalepka 2009), because the percentage graphs do not meet the methodological requirements. This chapter discusses and interprets the results based on the presence or absence of sporomorphs in the analysed pollen spectra. The sediment from all three examined sites on the Wawel Hill - Wawel IX (Wasylikowa et al. 2009), the Royal Gardens (Nalepka 2009) and the basement of building no. 9 (current examination) - did not accumulate as it would have done in, for example, a natural basin.

The interpretation based on percentage calculations or on raw data does not meet the conditions for performing statistical analyses. The deposition of sporomorphs in the studied profiles, and thus in the palynological samples, was not subject to the processes typical of lake or peat sediments. The accidental deposition of sporomorphs and the possibilities of their conservation in the forming profiles played a much greater role here.

For conducting statistical analysis, regardless of biological knowledge, the results obtained in the individual studied profiles were analysed by recording the presence of a given palynological taxon as 1 (absence from the table is denoted as zero). The list of all identified pollen taxa in the studied profiles is presented in Table 5 .

Biologically defined classes of taxa contain from 1 to 24 individual taxa. It is obviously interesting how many objects belong to those classes. However, having such a diverse number of taxa per class, it is also interesting to determine how many observations we have on average per taxon. This information is shown in Fig. 10a. The classes are sorted, as is evident from the diagram, according to the average number calculated. In the first two positions are classes named "human", but two other "human" classes are among the last ones. This indicates a high degree of variance, which may be open to interpretation. In Fig. $10 \mathrm{~b}$, the average numbers are broken down between the three sites. Visible, to some extent, is the lack of correlation between sites. This is addressed more precisely using the Phi coefficient of correlation. Of the three coefficients, one is almost exactly zero, and the two larger values are of opposite sign; however, both lack statistical significance. The p-value, calculated according to the Chi-square distribution, is 0.2. 


\section{CONCLUSIONS}

The sources of the sporomorphs (pollen grains and spores of non-vascular plants) present in the examined material from three profiles from the Wawel 2017 site are local habitats around the Wawel Hill and on the Hill itself. At the time, this locality had an open landscape in which a mosaic of communities developed, including wet meadows and thickets as well as ruderal, arable and forest communities, which is consistent with the current picture of the vegetation of the last millennium.

It cannot be excluded that some sporomorphs arrived at the site by human agency accidentally or were transported to Wawel for utility purposes.

Sporomorphs survived only in the upper layer of the two profiles studied (Wawel 2017 NW and Wawel 2017 SE). Probably, the examined sediment was not cut off from air access in the past (it was ventilated, and thus exposed to aerobic conditions), which led to the destruction of sporomorphs under aerobic conditions (combustion, oxidation, decomposition). The presence of sporomorphs only in the upper layer of the studied profiles can be explained by the fact that this level was exposed for a short time, after which it was quickly covered with a layer that cut off the profile from air access.

\section{Acknowledgments}

We are grateful to the Wawel Royal Castle and the National Art Collection for entrusting us with this valuable research material and funding of radiocarbon (AMS) dating. The archaeological research was supported by Wawel Royal Castle. The palaeobotanical investigations were party supported by statutory fund of the W. Szafer Institute of Botany, Polish Academy of Sciences, Cracow, and by the statutory fund of the Faculty of Geology, Geophysics and Environmental Protection, AGH University of Science and Technology, Cracow, Poland.

\section{References}

Berglund B. E. and Ralska-Jasiewiczowa M. 1986. Pollen analysis and pollen diagrams. In B. E. Berglund and M. Ralska-Jasiewiczowa (eds), Handbook of Holocene Palaeoecology and Palaeohydrology. Chichester, New York: J. Wiley \& Sons, 455-484.

Beug H. J. 2004. Leitfaden der Pollenbestimmung für Mitteleuropa und angrenzende Gebiete. München: Verlag Dr. Friedrich Pfeil.

Faegri K., Kaland P. E. and Krzywinski K. 1989. Textbook of pollen analysis. IV Edition. ChichesterSingapore: Wiley \& Sons Ltd.

Goslar T. 2019. Raport z wykonania datowania C-14 w Poznańskim Laboratorium Radiowęglowym, nr pracy 14908/19. Archive ZKnW. Kraków. 
Gwizdałówna J. 1995. Zieleń Wzgórza Wawelskiego. Przemiany dziejowe. Część 1. Gród i zamek obronny, 9-18 wiek (summary: Greenery of the Wawel Hill. Historical transformation 1. Garden and fortifi ed castle, $9^{\text {th }}$-18th cent.). Teka Komisji Urbanistyki i Architektury, 27, 21-34.

Kukliński A. 2016. Wczesnośredniowieczna stratygrafia kulturowa w południowo-zachodniej części wzgórza wawelskiego. Acta Archaeologica Waweliana 5.

Kukliński A. in print. Ślady wczesnośredniowiecznego osadnictwa z okresu pomiędzy 2. połową wieku VIII a wiekiem XIII w południowo-zachodniej części wzgórza wawelskiego - wyniki badań archeologicznych w wykopie 1/17, rejon IX w piwnicach budynku dawnego szpitala austriackiego, w bliskim sąsiedztwie krawędzi wzgórza. Acta Archaeologica Waweliana 6.

Latałowa M., Ralska-Jasiewiczowa M., Miotk-Szpiganowicz G., Zachowicz J. and Nalepka D. 2004. Fagus sylvatica L. Beech. In M. Ralska-Jasiewiczowa, M. Latałowa, K. Wasylikowa, K. Tobolski, E. Madeyska, H. E. Wright and C. Turner (eds), Late Glacial and Holocene history of vegetation in Poland based on isopollen maps. Kraków: W. Szafer Institute of Botany Polish Academy of Sciences, 95-104.

Makohonienko M. 2014. Środowisko przyrodnicze i gospodarka w otoczeniu średnioweicznego grodu w Łęczycy w świetle analizy palinologicznej. In R. Grygiel and T. Jurek (eds), Początki Łęczycy. Łódź: Muzeum Archeologiczne i Etnograficzne w Łodzi, 95-189.

Makohonienko M. and Nalepka D. 2007. Palinologia w badaniach stanowisk archeologicznych w Polsce. Palynological studies of archaeological sites in Poland. In M. Makohonienko, D. Makowiecka and Z. Kurnatowska (eds), Studia interdyscyplinarne nad środowiskiem i kultura $w$ Polsce (= Środowisko - człowiek - cywilizacja 1). Poznań: Bogucki Wydawnictwo Naukowe, 189-208.

Moore P. D., Collinsson M, and Webb J. A. 1991. Pollen Analysis. 2nd Edition. Oxford: Blackwell Scientific Publications.

Nalepka D. 1999. Analiza pyłkowa kopalnych i współczesnych poziomów glebowych - problemy metodyczne. Roczniki Gleboznawcze 50, 135-153.

Nalepka D. 2009. Are sporomorphs collected from the Wawel renaissance Gardens indicative of herbs cultivated by Queen Bona Sforza (1494-1557)? Acta Palaeobotanica 49, 353-364.

Nalepka D. and Walanus A. 2003. Data processing in pollen analysis. Acta Palaeobotanica 43, 125134 .

Okuniewska-Nowaczyk I., Milecka K., Makohonienko M., Harmata K., Madeja J. and Nalepka D. 2004. Secale cereale L. - Rye. In M. Ralska-Jasiewiczowa, M. Latałowa, K. Wasylikowa, K. Tobolski, E. Madeyska, H. E. Wright and C. Turner (eds), Late Glacial and Holocene history of vegetation in Poland based on isopollen maps. Kraków: W. Szafer Institute of Botany Polish Academy of Sciences, 347-353.

Reimer P. J., Bard E., Bayliss A., Beck J. W., Blackwell P. G., Ramsey C. B., Buck C. E, Cheng H., Edwards R. L., Friedrich M., Grootes P. M., Guilderson T. P., Haflidason H., Hajdas I., Hatté C., Heaton T. J., Hoffmann D. L., Hogg A. G., Hughen K. A., Kaiser K. F., Kromer B., Manning S. W., Niu M., Reimer R. W., Richards D. A., Scott E. M., Southon J. R., Staff R. A., Turney C. S. M. and Plicht J. van der 2013. IntCal13 and Marine13 Radiocarbon Age Calibration Curves 0-50,000 Years cal BP. Radiocarbon 55, 1869-1887. 
Stockmarr J. 1971. Tablets with spores used in absolute pollen analysis. Pollen et Spores 13, 615-621.

Wasylikowa K. 1978a. Early and Late Medieval plant remains from Wawel Hill in Cracow (9-10 ${ }^{\text {th }}$ to $15^{\text {th }}$ century A.D.). Berichte der Deutschen Botanischen Gesellschaft 91, 107-120.

Wasylikowa K. 1978b. Plant remains from Early and Late Medieval time found on the Wawel hill in Cracow. Acta Palaeobotanica 29, 115-200.

Wasylikowa K. 1991. Roślinność wzgórza wawelskiego we wczesnym i późnym średniowieczu na podstawie badań paleobotanicznych. Studia do Dziejów Wawelu 5, 93-131.

Wasylikowa K., Tomczyńska Z. and Nalepka D. 2006. Szczątki roślinne z warstw wczesnośredniowiecznych z rejonu IX na Wawelu. Acta Archaeologica Waweliana 3, 135-143. 
